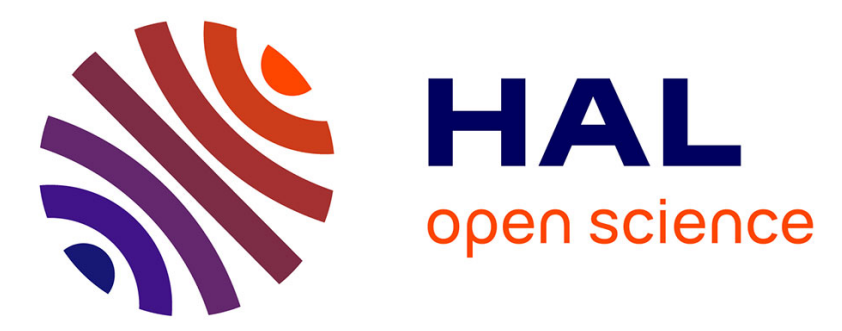

\title{
Cryptic lineages and high population genetic structure in the exploited marine snail Hexaplex trunculus (Gastropoda: Muricidae)
}

\author{
Zined Marzouk, D. Aurelle, Khaled Said, Anne Chenuil
}

\section{To cite this version:}

Zined Marzouk, D. Aurelle, Khaled Said, Anne Chenuil. Cryptic lineages and high population genetic structure in the exploited marine snail Hexaplex trunculus (Gastropoda: Muricidae). Biological Journal of the Linnean Society, 2017, 122 (2), pp.411-428. 10.1093/biolinnean/blx070 . hal-01631348

\author{
HAL Id: hal-01631348 \\ https://hal.science/hal-01631348
}

Submitted on 29 Apr 2018

HAL is a multi-disciplinary open access archive for the deposit and dissemination of scientific research documents, whether they are published or not. The documents may come from teaching and research institutions in France or abroad, or from public or private research centers.
L'archive ouverte pluridisciplinaire HAL, est destinée au dépôt et à la diffusion de documents scientifiques de niveau recherche, publiés ou non, émanant des établissements d'enseignement et de recherche français ou étrangers, des laboratoires publics ou privés. 
Cryptic lineages and high population genetic structure in the exploited marine snail Hexaplex trunculus (Gastropoda... 


\title{
Cryptic lineages and high population genetic structure in the exploited marine snail Hexaplex trunculus (Gastropoda: Muricidae)
}

\author{
ZINED MARZOUK ${ }^{1 *}$, DIDIER AURELLE ${ }^{2}, \mathrm{KHALED} \mathrm{SAID}^{1}$ and ANNE CHENUIL ${ }^{2}$ \\ ${ }^{1}$ Université de Monastir, ISBM, Laboratoire de recherche de Génétique, Biodiversité et Valorisation des \\ Bio-ressources (LR11ES41), 5000 Monastir, Tunisie \\ ${ }^{2}$ Aix Marseille Univ, Univ Avignon, CNRS, IRD, IMBE, 13007 Marseille, France
}

\begin{abstract}
Although the banded murex Hexaplex trunculus (Linnaeus, 1758) has no dispersal stage, it is widely distributed in a relatively broad range of habitats. These features make it a particularly suitable model to reconstruct the history of the fragmentation of its geographical range. We investigated its genetic structure from the eastern Mediterranean to the Atlantic coast, by sequencing a nuclear intron (i29) and a mitochondrial marker (cox1). We found strong genetic differentiation between all population pairs, congruent with the absence of a dispersing larval stage. A deep phylogeographical break separated two parapatric lineages, a western lineage (I) and an eastern one (II). The two lineages were separated by a vicariance event dated to the Pliocene by both markers, analysed independently. They co-occur in southern Italy and in the Siculo-Tunisian straight, where some individuals display recombined genotypes (lineage I for one marker, lineage II for the other), suggesting that introgression occurred in sympatric populations. We were unable to determine whether the vicariance was across the STS or located further east across the Peloponnese Arc, but the presence of lineage $\mathbf{I}$ in the northern Adriatic is more parsimoniously explained by a more eastern vicariance. Lineage I displayed a stronger signal of demographic expansion than lineage II, and its expansion was estimated to be more recent. This result, which has been reported in other marine species, suggests less drastic conditions for the eastern (and possibly also the central) Mediterranean benthos than for western populations during past climatic oscillations. The parapatric distribution still observed today suggests that human exploitation of this snail, which dates back to Antiquity, did not result in efficient introductions among basins, although present-day introductions were recently reported in the Bay of Biscay.
\end{abstract}

ADDITIONAL KEYWORDS: banded Murex - cox1 - genetic variability - Mediterranean Sea - north-eastern Atlantic - nuclear intron.

\section{INTRODUCTION}

The marine environment is considered to be fertile for cryptic speciation (i.e. species that are not distinguishable morphologically), suggesting that marine biodiversity has been underestimated at the species level (Knowlton, 1993; Féral, 2002). Several genetic studies of marine organisms in the Mediterranean Sea and the north-eastern Atlantic Ocean have revealed the existence of cryptic species complexes, highlighting the evolutionary processes that shaped the genetic diversity within these complexes (e.g. Boissin, Féral \& Chenuil, 2008; Calvo et al., 2009; Krebes et al., 2010; Boissin, Hoareau \& Berrebi, 2011a; Modica et al., 2013; Durand \& Borsa, 2015).

The biogeography of the Mediterranean sea has been shaped by a complex geological history since the closure of the Tethys (during the Miocene), passing through the Messinian Salinity Crisis, the Pliocene inundation from the Atlantic Ocean and Pleistocene glacial episodes (Patarnello, Volckaert \& Castilho, 2007; Sabelli \& Taviani, 2014; and references therein). Traces of past Tethys distribution ranges are reflected in the present distributions of several taxa, either in 
the distinct species of a genus (e.g. Posidonia, Aires et al., 2011) or between cryptic species of a given nominal species (Egea et al., 2016). Independently of past events, numerous studies report a role of contemporary physical barriers in shaping the distribution of the genetic diversity of marine organisms in the Mediterranean Sea and the north-eastern Atlantic Ocean (Duran et al., 2004; Patarnello et al., 2007; Maggs et al., 2008; Zitari-Chatti et al., 2009; Maltagliati et al., 2010; Tarnowska et al., 2010; Boissin, Stöhr \& Chenuil, 2011b; Fadhlaoui-Zid et al., 2012). Such barriers are created by distinct hydrological and ecological conditions that may be sufficient to reduce gene flow even on a relatively small geographical scale within seemingly continuous populations (Hellberg, 2009). These barriers to dispersal often coincide with contact zones between differentiated lineages, which can be explained by the dynamics of hybrid zones causing their displacement and stabilization in ecotones or lower carrying capacity areas (Barton, 1979).

Species life-history traits such as dispersal ability may have a major influence on the level and structuring of genetic diversity (Weber et al., 2015, but see also Boissin et al., 2015). A strong dispersal potential enhances genetic homogenization among populations throughout the distribution range of a species, whereas restricted dispersal (absence of larval phase or nektobenthic larvae, and sessile or sedentary adults) may lead to strong population differentiation and increased speciation rates (Kelly \& Palumbi, 2010; Boissin et al., 2011b). Oceanographic barriers do not affect all marine species in the same way, and some species do not display deep phylogeographical breaks (Patarnello et al., 2007; Aurelle et al., 2011). The link between life-history traits and the impact of these barriers (Patarnello et al., 2007), as well as the correlation between potential dispersal and observed levels of genetic differentiation, are not straightforward (Selkoe \& Toonen, 2011). It is often difficult to distinguish the impact of habitat fragmentation from that of low dispersal ability, as both contribute to increased genetic differentiation (e.g. Tarnowska et al., 2012). Species displaying narrow habitats and high dispersal are relatively rare, like low dispersers with wide niches.

The muricid gastropod, Hexaplex trunculus, is a common inhabitant of the Mediterranean Sea and adjacent Atlantic coasts (Madeira and Canary archipelagos, and the Moroccan and Portuguese coasts). This species occurs in intertidal and infralittoral zones between 1- and 100-m depth. It inhabits both hard and soft substrates, from rocky to sandy-muddy shores (Chiavarini et al., 2003). Hexaplex trunculus is a gonochoric species with collective spawning, which produces intracapsular development larvae (no planktonic larval stage). It is also highly restricted in mobility at the adult stage, which potentially limits its colonization ability (Vasconcelos et al., 2004). This species has been harvested by humans since prehistoric times (Fernandez-Lopez de Pablo \& Gabriel, 2016). It had high commercial value since Antiquity as a dye provider (Valenzuela, 2015), and more recently for human consumption. Recent studies found it a potential source of gelatin for industry (Zarai et al., 2012), and it is a sensitive bioindicator of organic pollution via imposex (Anastasiou et al., 2016). Given its wide geographical distribution, relatively low habitat fragmentation (unlike intertidal gastropods) and its highly restricted dispersal ability, we considered $H$. trunculus to be an ideal candidate for studying physical and evolutionary factors inducing population genetic structure in the Mediterranean Sea and the north-eastern Atlantic Ocean.

To date, few studies have been carried out on the population genetics of $H$. trunculus. González-Tizón et al. (2008) compared the genetic diversity of the harvested population from Ria Formosa (southern Portugal) with two adjacent populations in order to provide source populations for stock enhancement. Villamor, Costantini \& Abbiati (2014) characterized Italian populations from the Ligurian, Tyrrhenian, Ionian and Adriatic Seas, encompassing putative biogeographical barriers for the cox 1 marker, and reported strong genetic differentiation across the Siculo-Tunisian strait, with a potential gene flow from Ligurian-Tyrrhenian towards Ionian-Adriatic populations. However, these studies were based on a single mitochondrial marker and/or were geographically too restricted to address the genetic variability of $H$. trunculus across its distribution range or to identify major genetic divisions. Recently, a morphometric study, based on shell characters (such as shell height, aperture length etc.) from 17 locations throughout the whole distribution area of the species strongly suggested the presence of four main groups corresponding to different geographical areas: the Atlantic; the Alboran Sea; the western Mediterranean (France, northern Tunisia and the Siculo-Tunisian strait); and an extensive eastern Mediterranean group grouping eastern Tunisian, Adriatic and Greek populations (Marzouk et al., 2016). This structure was evidenced by multidimensional scaling (MDS), hierarchical clustering analysis and canonical discriminant analysis. All morphometric indices were significantly differentiated between groups. Since morphology may be influenced by environment, through developmental plasticity, genetic markers were necessary to establish the validity of this phylogeographical pattern and, in the case of long-term divergence, to estimate its age. Such data are also crucial to optimize the management of this exploited resource. 
In the present study, we investigated the genetic structure of $H$. trunculus at 19 localities, including those of the morphological study (Marzouk et al., 2016), for a mitochondrial marker ( $\operatorname{cox} 1)$ and a nuclear intron (i29). In addition, we included data from the six locations characterized by Villamor et al. (2014) and one cox1 sequence of a specimen from Haifa (Levantine Sea) retrieved in the BOLD-system database (Ratnasingham $\&$ Hebert, 2013). On the basis of extensive sampling coverage, we investigated (1) the main phylogeographical splits and the possibility of distinct species and secondary contacts within the nominal species $H$. trunculus, (2) its genetic structure at a smaller geographical scale and (3) its demographic history.

\section{MATERIAL AND METHODS}

\section{SAMPLE COLLECTION}

Samples were collected from 19 localities across most of the distribution range of this species (Fig. 1; Table 1). All specimens were collected between 0.5- and 30-m depth from January 2009 to July 2013. Collected samples were consistent with the taxonomic description of the species by Houart (2001). Following capture, samples were transported to the laboratory, and a small portion of foot tissue was cut and preserved in absolute ethanol at $-20^{\circ} \mathrm{C}$ until further processing. A hundred published $\operatorname{cox} 1$ sequences (GenBank accessions: KF297407-KF297433) from six Italian populations and a single specimen from
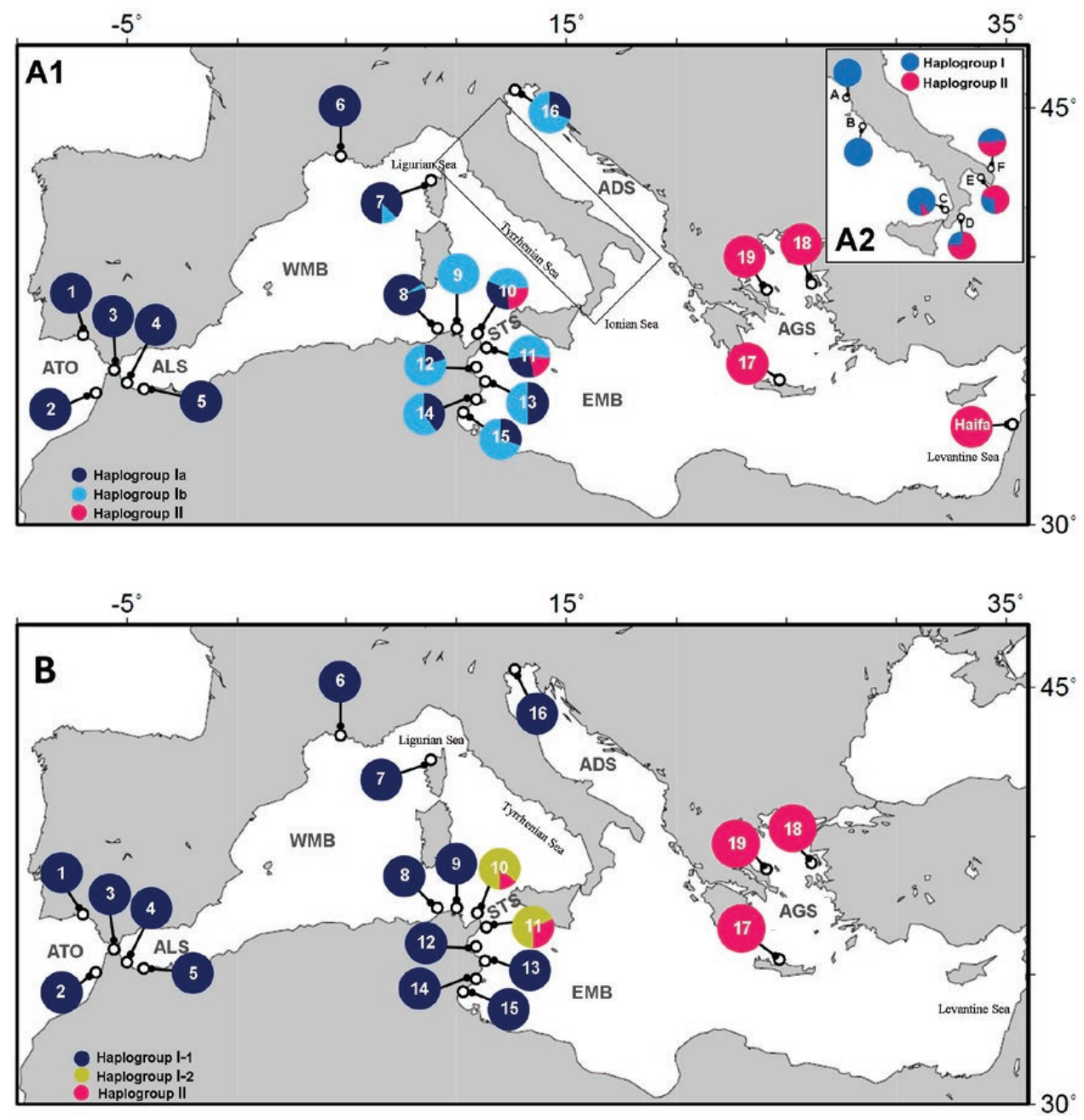

Figure 1. Map showing the sampling sites of Hexaplex trunculus. Numbers $(1 \rightarrow 19)$ are populations sampled in the present study (see Table 1 for details), Letters $(\mathrm{A} \rightarrow \mathrm{F})$ are the six populations studied by Villamor et al. (2014). Pie charts show the distribution of the major haplogroups for $\operatorname{cox} 1$ ( $\mathrm{A}_{1}$ : present study, $\mathrm{A}_{2}$ : Villamor et al., 2014) and for $i 29$ (B). For the cox1 sequences of Villamor et al. (2014), it was not possible to distinguish haplogroups Ia and Ib due to shorter sequence length. ATO, Atlantic Ocean; ALS, Alboran Sea; WMB, Western Mediterranean Basin; STS, Siculo-Tunisian Strait; EMB, Eastern Mediterranean Basin; ADS, Adriatic Sea; AGS, Aegean Sea. 


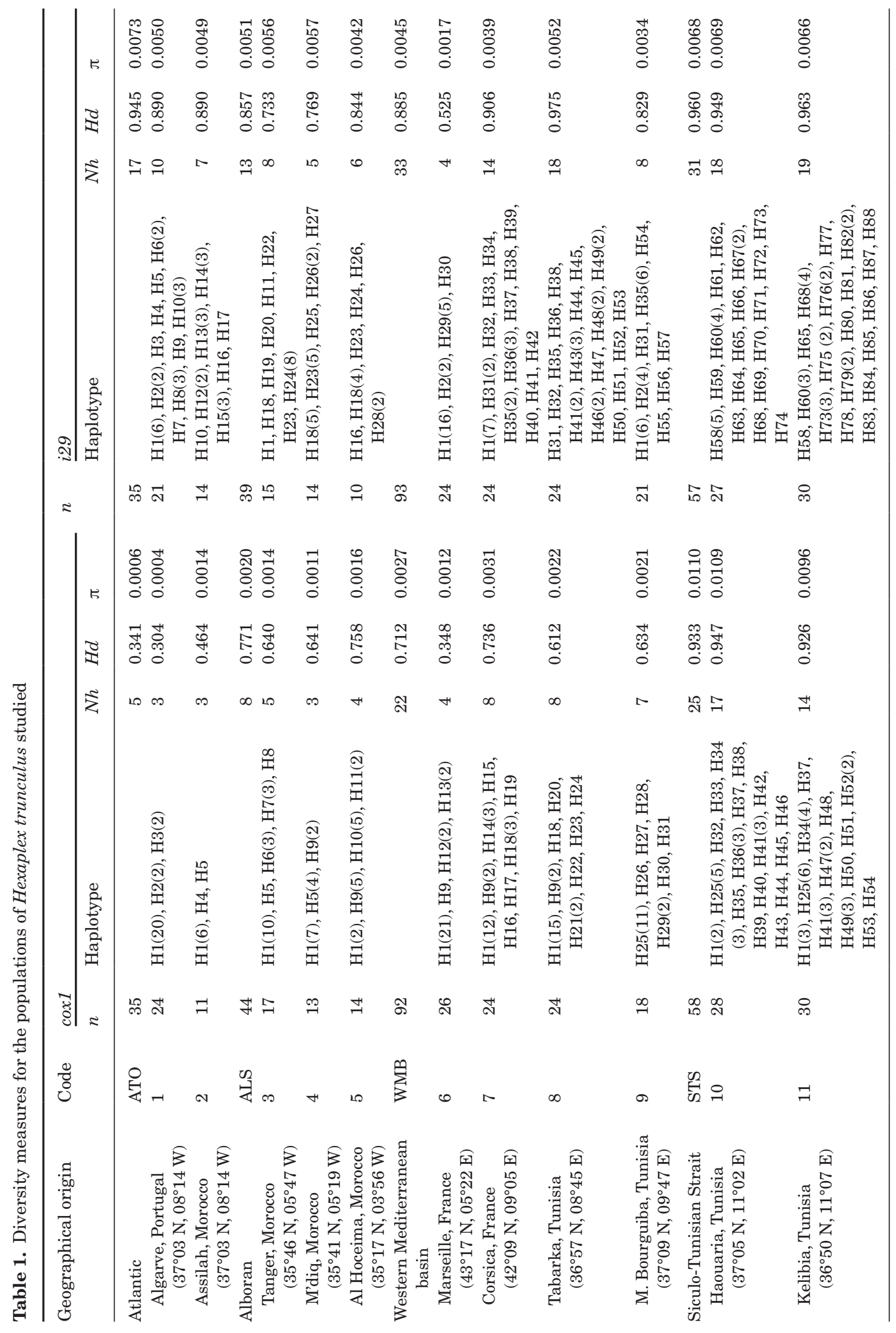




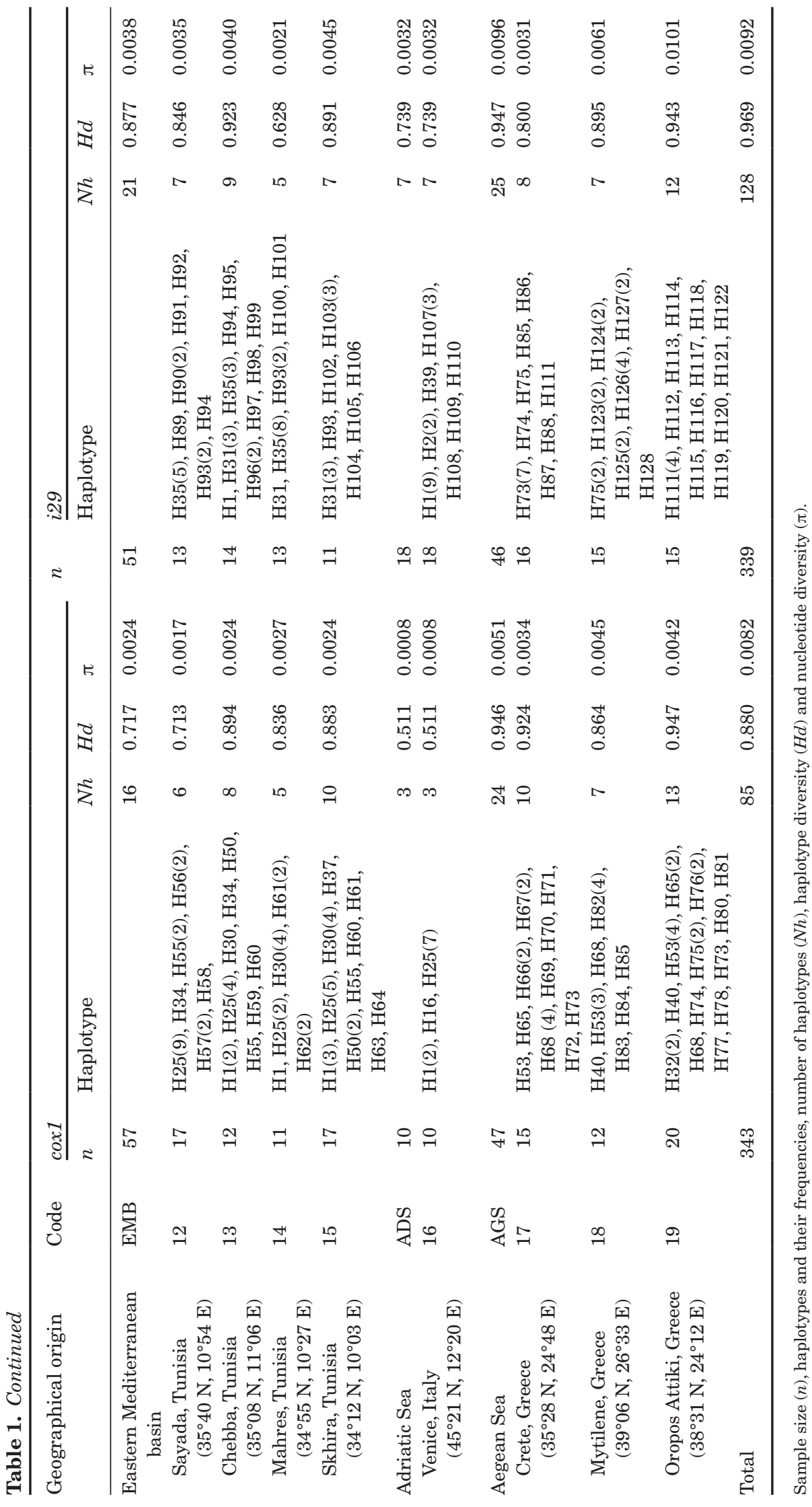


Haifa (Levantine Sea) (BOLD record ID: 3443789) were included in our analysis (Fig. 1).

\section{DNA EXTRACTION, AMPLIFICATION AND SEQUENCING}

Total genomic DNA was extracted with Chelex resin (Bio-Rad) solution at 10\% (Walsh, Metzger \& Higuchi, 1991) and preserved at $-20^{\circ} \mathrm{C}$. PCR was used to amplify (1) $710 \mathrm{bp}$ of the mitochondrial Cytochrome Oxydase I gene (cox 1), using the primers LCO1490 and HCO2198 from Folmer et al. (1994) and (2) $581 \mathrm{bp}$ of the EPIC (Exon Primed Intron Crossing) marker i29 that was successfully amplified in gastropods and bivalves in a recent study (Gérard et al., 2013). For $i 29$, we used the primers HTi29F1 and HTi29R2, which were designed from sequence data of the fragment, amplified with universal primers developed by Chenuil et al. (2010). The sequences of the primers are HTi29F 1: 5'AGAGACAGACACACTGTCTGAC-3' and HTi29R2: 5'-TCCGTGGTCTCCCACACACAAT-3' .

The cox1 marker exhibits levels of sequence variation suitable for population analysis of numerous marine invertebrates (Reuschel \& Schubart, 2006; Pérez-Losada et al., 2007; Calvo et al., 2009; Zitari-Chatti et al., 2009; Penant et al., 2013; but see Calderón, Garrabou \& Aurelle, 2006). The nuclear intron i29, like many other EPIC markers, is conserved in position across many metazoans, yet is potentially highly polymorphic (Chenuil et al., 2010). PCR were conducted in a Mastercycler Epgradient S from Eppendorf using the following programs. (1) For cox 1 , initial denaturation $3 \mathrm{~min}$ at $94{ }^{\circ} \mathrm{C}, 35$ cycles, denaturation $1 \mathrm{~min}$ at $94{ }^{\circ} \mathrm{C}$, primer annealing for $1 \mathrm{~min}$ at $42{ }^{\circ} \mathrm{C}$, extension for $1 \mathrm{~min}$ at $72^{\circ} \mathrm{C}$ and final elongation for $5 \mathrm{~min}$ at $72{ }^{\circ} \mathrm{C} \mathrm{PCR}$ reactions were carried out in $25-\mu \mathrm{L}$ reaction volumes, with $1 \times$ buffer, $2 \mathrm{mM} \mathrm{MgCl}{ }_{2}, 0.2 \mathrm{mM}$ dNTP, $2 \mu \mathrm{M}$ of each primer, $1 \mathrm{U}$ Taq polymerase (Promega) and $2 \mu \mathrm{L}$ of DNA. (2) For $i 29$, the PCR programme was similar as for cox1, but the annealing temperature was $50{ }^{\circ} \mathrm{C}$ and the final elongation step lasted $8 \mathrm{~min}$. PCR products were sequenced on $\mathrm{ABI}$ automated sequencers at the LGC Genomics Firm using the LCO1490 or the HTi29F1 primers. For each marker, a first set of 24 individuals was also sequenced with the opposite primer. On the basis of the results (see below), we decided to use a single primer for sequencing.

\section{PHYLOGENETIC ANALYSES AND DATING}

Sequences were aligned using ClustalW (Thompson, Higgins \& Gibson, 1994) implemented in Bioedit (Hall, 1999). The DNA sequences were deposited in the GenBank database with the following accession numbers: KJ135221-KJ135286 and KT934232KT934250 for cox1 and KT934104-KT934231 for $i 29$.

We used the NETWORK software (Bandelt, Forster $\&$ Rohl, 1999) to reconstruct haplotype networks. We used SplitsTree4 (Huson \& Bryant, 2016) to perform the Phi-test of the hypothesis that recombination occurred in $i 29$ and to compare several methods of network reconstruction. Phylogenetic reconstructions were performed using (1) maximum likelihood algorithms in Phyml online at the ATGC Montpellier bioinformatics platform (Guindon et al., 2005) and (2) Bayesian inference (BI) in BEAST (Drummond \& Rambaut, 2007). All analyses were performed using the HKY + I + G model (Hasegawa, Kishino \& Yano, 1985), as determined by the JModelTest (Posada, 2008). Sequences of Bolinus brandaris (GenBank accession numbers: DQ280020 and KU821678) and Nucella lapillus (GenBank accession number: EU391582) were used as outgroups. A hundred bootstrap replicates were performed for Phyml. BI reconstruction implemented in BEAST v1.7.2 (Drummond \& Rambaut, 2007) was used under a strict clock and Yule (pure birth) process as a model of speciation to estimate TMRCA (time to the most recent common ancestor) and their credibility intervals (95\% HPD). To calibrate the $\operatorname{cox} 1$ analyses, we used a fossil calibration of 40 Mya for the divergence between N. lapillus and the clade grouping Hexaplex/Bolinus, following Merle, Garrigues \& Pointier (2011 and pers. commun.). Then, the divergence time between Hexaplex and Bolinus deduced from the BEAST phylogenetic analyses on $\operatorname{cox} 1$ was used to calibrate the i29 analyses.

Posterior distributions of parameters were approximated using five independent MCMC analyses of 20 million generations with $10 \%$ burn-in. Samples from the two runs, which yielded similar results, were combined, and convergence of the chains was checked using the program Tracer v1.6 (Drummond \& Rambaut, 2007). Results were analysed and visualized with TreeAnnotator v1.7.2, using the maximum clade credibility tree and mean node heights, and with FigTree v1.4 (Rambaut, 2009).

\section{GENETIC DIVERSITY AND STRUCTURE}

Nucleotide and haplotype diversities $(\pi, H d)$ were calculated using the DNAsp software (Librado \& Rozas, 2009). Differentiations between population pairs were estimated with pairwise $F_{\mathrm{ST}}$ and $\Phi_{\mathrm{ST}}$ statistics. ARLEQUIN was used (Excoffier \& Lischer, 2010) to compute $F_{\mathrm{ST}}$ and $\Phi_{\mathrm{ST}}$, and the null hypothesis of no differentiation was tested by performing 10000 permutations. The Benjamini \& Hochberg (1995) correction for multiple tests was applied. Kimura two-parameters 
(K2P) mean genetic distances between lineages were computed, for both markers, in MEGA5 (Tamura et al., 2011).

\section{MDS BASED ON GENETIC DISTANCES BETWEEN POPULATIONS}

Ordinal MDS analyses, based on $\Phi_{\mathrm{ST}}$ pairwise genetic distances between populations, were performed using XLSTAT (AddinSoft, 2007) to visualize relationships among populations with the two distinct markers. Populations were coloured according to their morphological group assignment, which was spatially interpolated for the two populations without morphological data (Marzouk et al., 2016), Corsica and Tabarka.

\section{MULTILOCUS ANALYSES OF INDIVIDUALS IN AREAS OF SYMPATRY AMONG MITOCHONDRIAL HAPLOGROUPS}

Since very divergent haplogroups were found in cox 1 (see Results), we tested the hypothesis that those haplogroups corresponded to separate biological species (Mayr, 1942). Under this hypothesis, when in sympatry, these species should not exchange genes efficiently (hybrids should be unviable or sterile). Thus, genetic differentiation for the nuclear marker should be observed between mitochondrial groups within populations. We thus built, for each population wherein distinct haplogroups coexisted, contingency tables splitting individuals based on their cox 1 and $i 29$ lineages. We then tested the hypothesis that $i 29$ lineages were independent of cox1 lineages using Fisher's exact tests.

\section{DEMOGRAPHIC HISTORIES}

Mismatch distributions of pairwise nucleotide differences (Rogers \& Harpending, 1992) in the main geographic regions (ATO, ALS, WMB, STS, EMB, ADS and AGS) were built using DNAsp. For neutral polymorphisms, when population sizes are constant, these distributions are generally chaotic, whereas in case of past demographic expansion, a unimodal curve is observed. Mismatch distributions were also performed separately for the main lineages found for each marker. We used ARLEQUIN (Schneider \& Excoffier, 1999) to compute the tau estimator and its confidence interval for the cox 1 marker. The tau statistic $(\tau)$, under a model of demographic expansion, estimates the expansion's starting time in mutational units, using the formula of $\mathrm{Li}$ (1977): $\tau=2 \mu t$, where $\mu$ is the mutation rate for the whole sequence and $t$ is the time in generation units. Mismatch distribution tests were reported to be conservative (Ramos-Onsins \& Rozas, 2002), thus we also computed Tajima's $D$ tests (Tajima, 1989), Fu's Fs (Fu, 1997) and Ramos-Onsins and Rozas's $R_{2}$ tests (Ramos-Onsins \& Rozas, 2002), implemented in DNAsp, for the cox 1 marker. Significance levels for these tests were calculated using 1000 coalescent simulations. When these parameter values depart from zero, the null hypothesis of demographic stability and selective neutrality of the cox 1 marker is rejected.

\section{RESULTS}

\section{GENETIC DIVERSITY}

A total of $343 \mathrm{H}$. trunculus cox 1 sequences of $658 \mathrm{bp}$ were obtained. Among them, 85 different haplotypes were identified; 51 sites were variable and 39 were parsimony informative. For the nuclear marker i29, 339 specimens were successfully sequenced for $500 \mathrm{bp}$, displaying 128 distinct haplotypes, 58 polymorphic sites, of which 45 were parsimony informative. Only one seventh of superimposed peaks were obtained for i29, after Sanger amplicon sequencing, probably due to individual heterozygosity at this marker. Most individuals displayed no ambiguity for their $i 29$ sequence. Some $i 29$ haplotypes were thus probably not detected. For this reason, data analyses did not use individual diploid genotypes at $i 29$. Polymorphism parameters are reported in Table 1 for each marker and each population.

\section{HAPLOTYPE NETWORKS, PHYLOGENETIC ANALYSES AND DATATIONS}

Haplotype networks and phylogenetic trees evidenced strong phylogeographical structures for both markers. The cox 1 network showed that the haplotypes were distributed into two main haplogroups (Fig. 2). Using cox 1 sequences of two outgroups, B. brandaris and $N$. lapillus, phylogenetic analyses recovered two lineages perfectly matching the two haplogroups (I and II). These main lineages were supported by bootstrap values higher than $80 \%$ and posterior probabilities higher than 0.97 (Fig. 3). The haplotype network showed that the haplogroup I could be divided into two groups of haplotypes: Ia, which was found in the Atlantic, Alboran, Marseilles, Corsica, Tunisia (except M. Bourguiba) and the Adriatic, and Ib, which was only found in Corsica, Tunisia and the Adriatic. The first lineage or haplogroup (I) displayed a star-like pattern (Fig. 2). The second haplogroup (II) was mainly composed of unique haplotypes from Aegean and Siculo-Tunisian samples and a few haplotypes shared between these two regions (Figs 1, 2). The two cox1 lineages ( $\mathbf{I}_{\boldsymbol{c o x} \boldsymbol{1}}$ and $\left.\mathbf{I I}_{\boldsymbol{c o x} \mathbf{1}}\right)$ were separated by seven mutations corresponding to a divergence of at least $1.06 \%$ among haplotypes between those lineages. The mean $\mathrm{K} 2 \mathrm{P}$ genetic distance was estimated at 0.024 between 

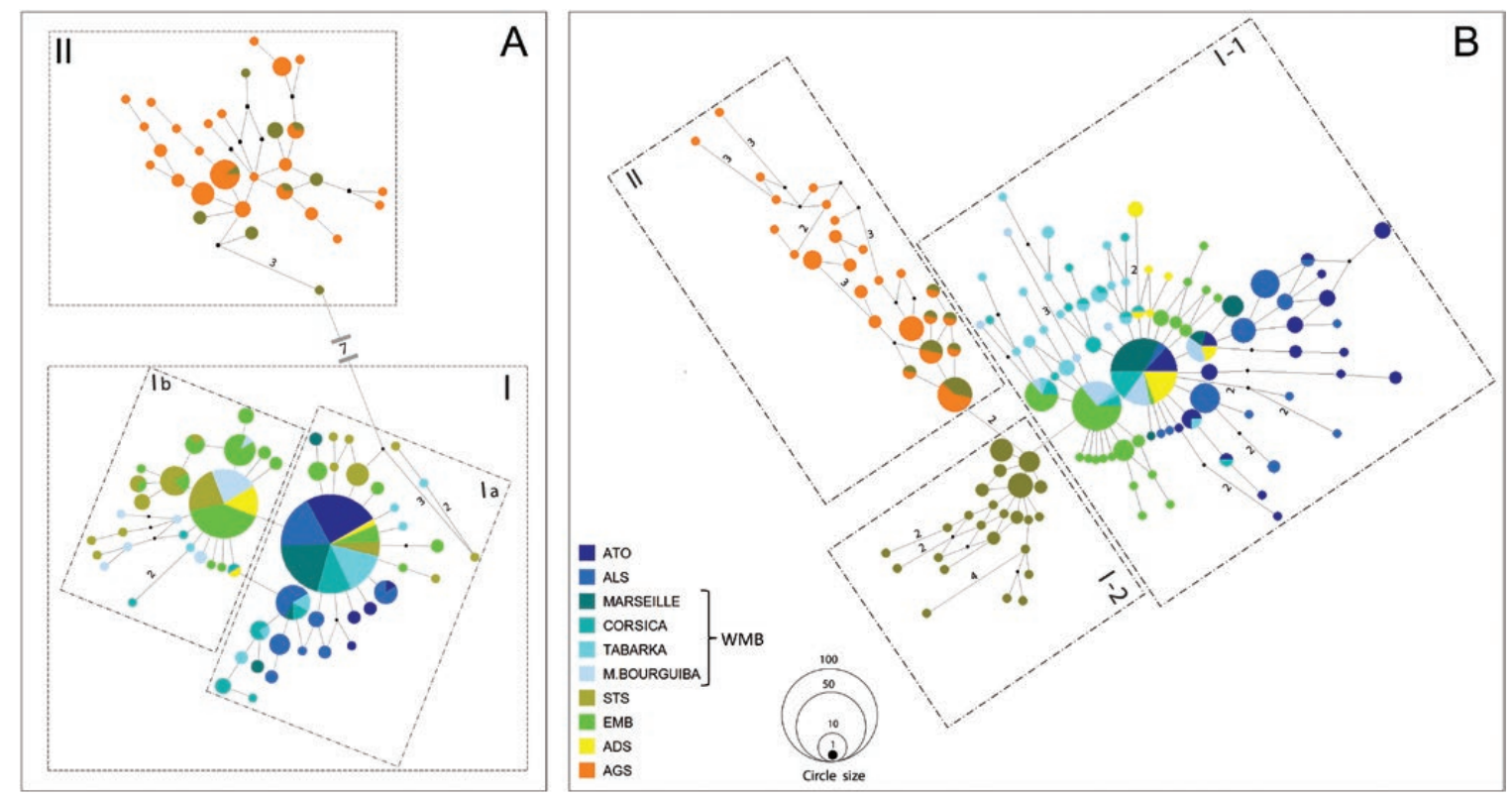

Figure 2. Haplotype networks for $\operatorname{cox} 1$ (A) and $i 29$ (B). Each circle represents an haplotype. The size of the circle is proportional to the number of individuals displaying each haplotype. Numbers of mutations (when more than one mutation separates the sequences) between haplotypes are indicated near branches. Colours indicate the origin of the individuals displaying each haplotype, as in the legend: to limit the use of colours, spatially close populations were combined according to the regions defined in Table 1, except for the four populations from the WMB region because (1) they may be very distant and (2) two very close localities (northern Tunisia) do not fall into the same haplogroup (for cox1). Black circles represent unsampled haplotypes.

cox1 lineages and 0.133 between $B$. brandaris and the two cox1 lineages. The divergence time between the two lineages $\left(\mathbf{I}_{\text {cox } 1}\right.$ and $\mathbf{I I}_{\text {cox } 1}$ ) was estimated at 5.18 Mya (95\% HPD 3.5-7.3), corresponding to the Pliocene. The estimated cox1 substitution rate mean value was 0.00295 substitutions per Mya $(\mathrm{SD}=0.000418)$ corresponding to the divergence rate of $0.6 \%$ per Mya. This was different from the cox 1 divergence rates estimated by Lessios (2008) and Miura, Torchin \& Bermingham (2010) (2.4-3.3\% per Mya), based on a marine gastropod in the Isthmus of Panama. Applying this rate provided a divergence time of about 1 Mya for the two $H$. trunculus lineages. When we integrated the cox 1 sequences published by Villamor et al. (2014) and by BOLD-system database (Ratnasingham \& Hebert, 2013) in our data set, the distinction between haplogroups Ia and Ib was lost because Villamor's fragment was smaller than ours (we truncated our sequence file to the fragment size of Villamor et al., 2014). We identified the two main haplogroups: $\mathbf{I}_{c o x}$ that occurred in the six Italian localities (A, B, C, D, E and F) and II $_{\text {cox } 1}$ occurring in the Tyrrhenian (C), Ionian (D and E), Adriatic (F) and Levantine (Haifa) Seas (Supporting Information, Appendix S1; Fig. 1).

The $i 29$ network showed two lineages (I and II) and three haplogroups (I-1, I-2 and II), which appeared less divergent (as \% of sequence differences) than the two mitochondrial ones (Fig. 2). The divergence value among $i 29$ lineages is $0.4 \%$. The mean K2P genetic distance was estimated at 0.019 between i29 lineages and 0.135 between $B$. brandaris and $i 29$ lineages.

As illustrated by Figure 2, the phylogeographical patterns are very similar between cox 1 and $i 29$, in particular: (1) Aegean populations display a single haplogroup and (2) this haplogroup is found nowhere else except in the two populations of the Siculo-Tunisian strait (STS). A particular feature for $i 29$ is the presence of a group of haplotypes ( $\mathbf{I - 2 _ { i 2 9 }}$ ), which is only found in the STS. Using phylogenetic trees for this marker, we recovered, with low node supports, the distinction between two main lineages $\left(\mathbf{I}_{i 29}\right.$ and $\left.\mathbf{I I}_{i 29}\right)$ and their divergence time was estimated at 5.21 Mya (95\% HPD 3.4-7.5) (Fig. 4), very similar to the divergence between $\mathbf{I}_{c o x \boldsymbol{x}}$ and $\mathbf{I I} \mathbf{I}_{\text {coxr }}$. Haplogroups $\mathbf{I}-\mathbf{1}_{i 29}$ and $\mathbf{I}-\mathbf{2}_{i 29}$ formed distinct clades in phylogenetic trees but were poorly supported.

In Tunisia, where the two main lineages are in contact, we investigated whether haplogroup $\mathbf{I}_{\mathbf{2}} \mathbf{i}_{\mathbf{2} 9}$, which is restricted to the Siculo-Tunisian strait, may have been generated by a recombination event between haplogroups $\mathbf{I}-\mathbf{1}_{i 29}$ and $\mathbf{I I}_{i 29}$, which are both present in Tunisian populations. For this, we compared the three haplogroups and checked in the sequence alignment whether one of them may have resulted from a 


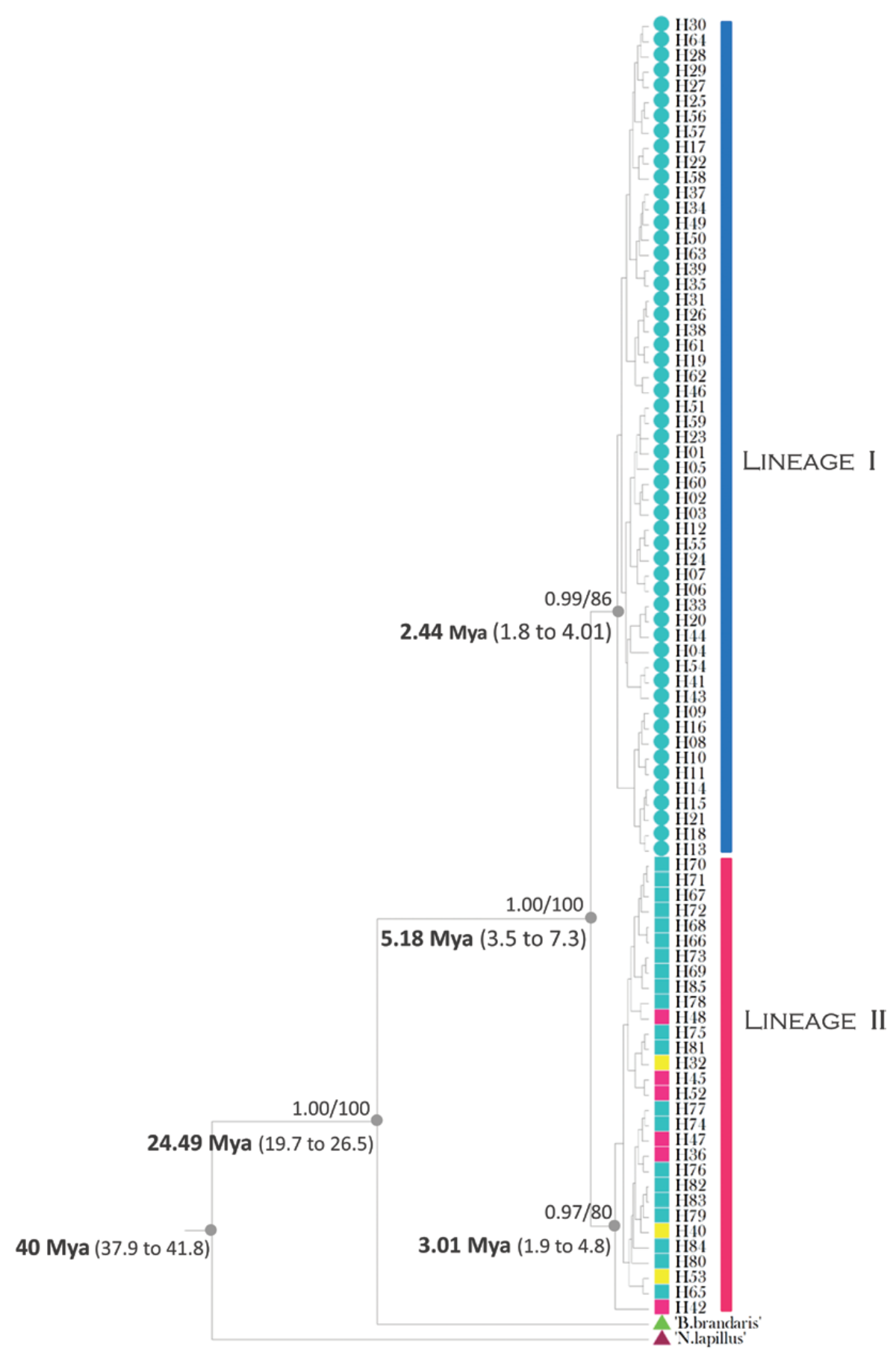

Figure 3. Bayesian reconstruction of phylogenetic relationships among cox1 haplotypes. Lineage I is symbolized by circles; Lineage II by squares, followed by numbers that indicate individual haplotypes. Yellow squares indicate haplotypes occurring in Siculo-Tunisian strait; red squares indicates occurrence of haplotype in both Aegean Sea and Siculo-Tunisian strait. Numbers above the branches show support values (Bayesian posterior probability for BI and bootstraps greater than 50\% for maximum likelihood reconstructions, respectively). Numbers below the branches show the TMRCA (Mya) with their confidence intervals. 


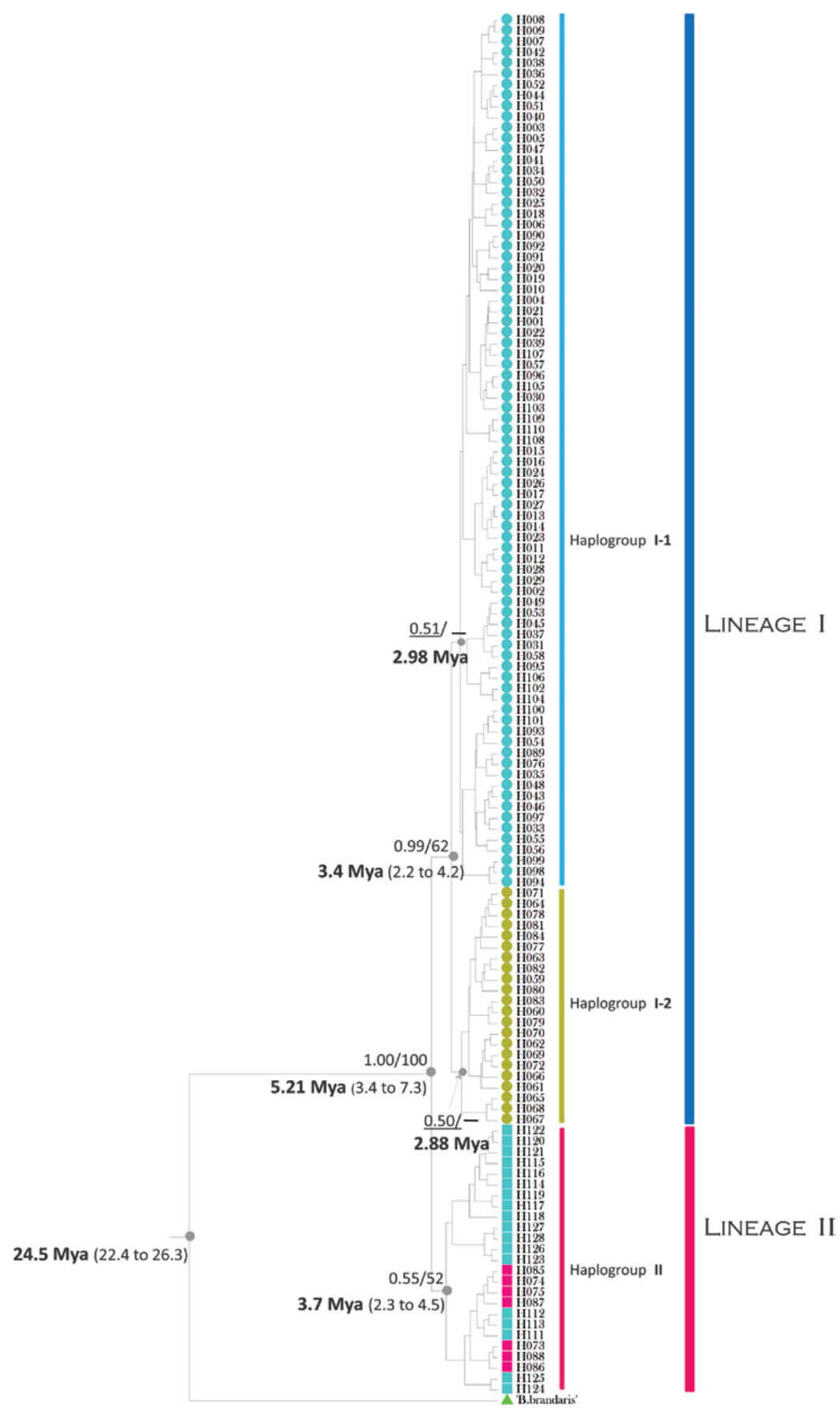

Figure 4. Bayesian reconstruction of phylogenetic relationships among $i 29$ haplotypes. Lineage I is symbolized by circles, blue circles indicate haplogroup I-1 and green circles indicate haplogroup I-2. Lineage II is symbolized by squares; red squares indicate haplotypes occurring in both Aegean Sea and Siculo-Tunisian strait. Numbers above the branches show support values (Bayesian posterior probability for BI and bootstraps greater than 50\% for maximum likelihood reconstructions, respectively). - Bootstraps $<50 \%$. Numbers below the branches show the TMRCA (Mya) with their confidence intervals. 
recombination between the other two: no pair of sites supported this hypothesis, thus recombination events cannot explain the peculiar geographical distribution of i29 haplogroups. The Phi-tests, both in the total data set and in the area of sympatry, were not significant, supporting the hypothesis that no recombination occurred in this DNA region.

\section{POPULATION DIFFERENTIATION}

For cox 1 and $i 29$, all pairwise comparisons between populations based on $F_{\mathrm{ST}}$, and nearly all of those based on $\Phi_{\mathrm{ST}}$, remained significant after correction for multiple tests (Benjamini \& Hochberg, 1995) (Supporting Information, Appendix S2). $F_{\mathrm{ST}}$ values were high for both markers (about 0.301 for cox 1 and 0.286 for i29), even between pairs of adjacent populations [e.g. $F_{\mathrm{ST}}(\operatorname{cox} 1)>0.6$ between the two Atlantic sites and $F_{\mathrm{ST}}(\operatorname{cox} 1)>0.3$ between adjacent Moroccan populations]. Overall, $\Phi_{\mathrm{ST}}$ was about 0.419 and 0.438 for cox 1 and $i 29$, respectively. MDS illustrated that genetic differentiation patterns were broadly compatible with morphological grouping (which were highly congruent with geography), although some differences were visible (Supporting Information, Appendix S3). The genetic difference between the Atlantic (with or without the Alboran Sea) and the Mediterranean Sea (excluding or not the Alboran Sea) was not salient, in contrast with the differentiation of Aegean localities vs. all other localities, which was striking for cox 1 , and very clear for $i 29$. The central position of samples from the STS in the MDS reflected the fact that they are a mixture of both cryptic lineages (species), so they are intermediate between Aegean Sea and other populations for both markers.

\section{MULTILOCUS TESTS FOR COX1 AND I29 HAPLOGROUPS ASSOCIATION IN INDIVIDUALS}

We built contingency tables to test the independence of the two genetic markers' major splits. This test was done within populations (to avoid the effect of genetic structure due to restricted dispersal) where the haplogroups I and II coexisted (Haouaria and Kelibia). In those tables, we distributed the individuals according to their belonging to major lineages for the cox 1 marker (raws) or i29 (columns) (Supporting Information, Appendix S4). Some heterogeneous or 'recombined' individuals displayed the eastern haplogroup (named II) for one marker and the western haplogroup (named I) for the other marker. The probability of obtaining a more skewed distribution (onesided Fisher's exact test) was $0.031^{*}$ for Haouaria and 0.049* for Kelibia, but the Fisher's exact tests were not significant (probability of obtaining a more or equally skewed distribution, respectively, 0.521 and 0.237 ). We thus cannot reject the null hypothesis that genes are randomly associated between these lineages in this area.

\section{NEUTRALITY TESTS AND MISMATCH DISTRIBUTIONS}

Mismatch distributions within regions were generally unimodal for both markers, suggesting population expansions (or past selective sweeps), except for the STS where the coexistence of distinct cox1 lineages generated clear-cut bimodality (one mode for intra-lineage, one for inter-lineage comparisons). The fact that bimodality was not observed for the i29 marker in the same region may be explained by the lower genetic divergence between lineages than for cox1. The mismatch distribution did not appear unimodal (nor unambiguously bimodal) for the Aegean Sea in i29 (Supporting Information, Appendices S5, S6; Fig. 2), a result compatible with a more stable demography. Numerous significant negative values of $F s$ and Tajima's $D$ (but $R_{2}$ values were often not significant) in cox 1 (Table 2) rule out the hypothesis of constant effective sizes and neutral polymorphism and suggest either selective sweeps or past demographic expansion. Since past population expansion is likely, it is of interest to examine tau parameters and corresponding expansion times (Table 2). They suggested a more recent and/or more extensive expansion in the lineages $\mathbf{I}_{\boldsymbol{c o x} \mathbf{1}}$ and $\mathbf{I}-\mathbf{1}_{\boldsymbol{i} 29}$ compared to lineages II (much more star-like haplotype networks). The most recent expansion was estimated for the Adriatic Sea (about 88 thousand years ago).

\section{DISCUSSION}

\section{POPULATIONS ARE GENETICALLY DIFFERENTIATED EVEN AT SMALL GEOGRAPHICAL SCALE}

Our analyses based on extensive geographical sampling evidenced strong genetic differentiation among populations of $H$. trunculus at different geographical scales. At small geographical distance, differentiation was revealed by high and significant $F_{\mathrm{ST}}$ values among all studied population pairs, even between the geographically closest ones (about $60 \mathrm{~km}$ between Moroccan populations and about 20-40 km between Tunisian populations). Since the habitat of $H$. trunculus is not particularly fragmented, reduced dispersal ability is the most likely cause of such a genetic structure. The benthic habit of the adults (Chiavarini et al., 2003), the benthic eggs hatching directly to nektobenthic juveniles and restricted mobility of both juveniles and adults (Vasconcelos et al., 2004) strongly limit dispersal distances. Several studies of 
Table 2. Neutrality tests, demographic parameter $(\tau)$ and expansion times (Mya) with their confidence intervals for cox1 marker

\begin{tabular}{lccclll}
\hline Geographical origin & $n$ & $D$ & $F s$ & $R_{2}$ & $\tau$ & ET \\
\hline Algarve & 24 & -0.89 & 0.92 & $0.08^{*}$ & $2.56(0.359-3.50)$ & $0.324(0.045-0.443)$ \\
Marseille & 26 & -1.10 & $-2.25^{* *}$ & $0.08^{*}$ & $2.07(0.346-4.09)$ & $0.262(0.043-0.517)$ \\
Corse & 24 & 0.24 & $-1.72^{* *}$ & 0.14 & $3.23(0.057-6.90)$ & $0.408(0.007-0.873)$ \\
Tabarka & 24 & $-1.85^{*}$ & $-2.85^{* *}$ & $0.09^{*}$ & $0.00(0.00-0.00)$ & Constant \\
Oropos Attiki & 20 & -0.04 & $-7.25^{* * *}$ & 0.12 & $2.99(1.89-4.09)$ & $0.378(0.239-0.517)$ \\
ATO & 35 & $-1.75^{*}$ & $-2.86^{* *}$ & 0.08 & $2.39(0.40-3.50)$ & $0.302(0.050-0.443)$ \\
ALS & 44 & 0.43 & $-2.02^{*}$ & 0.13 & $1.43(0.63-2.49)$ & $0.181(0.079-0.315)$ \\
WMB & 92 & -1.68 & $-15.50^{* * *}$ & 0.04 & $1.70(0.95-2.63)$ & $0.215(0.120-0.332)$ \\
STS & 58 & -0.31 & $-6.06^{*}$ & 0.11 & $14.5(4.5-17.46)$ & $1.835(0.569-2.210)$ \\
EMB & 57 & -1.05 & $-9.54^{* * *}$ & 0.06 & $2.40(0.89-5.32)$ & $0.303(0.112-0.673)$ \\
ADS & 10 & -0.69 & $-0.59^{*}$ & 0.17 & $0.70(0.00-1.56)$ & $0.088(0.000-0.197)$ \\
AGS & 47 & 0.13 & $-15.53^{* * *}$ & 0.11 & $3.73(1.82-5.13)$ & $0.474(0.057-0.162)$ \\
Lineage I & 283 & $-1.84^{* *}$ & $-64.79^{* * *}$ & $0.03^{*}$ & $0.59(0.00-0.97)$ & $0.074(0.000-0.122)$ \\
Lineage II & 60 & 0.21 & $-14.76^{* * *}$ & 0.08 & $3.80(0.94-5.82)$ & $0.481(0.118-0.736)$ \\
\hline
\end{tabular}

Geographical region (as in Fig. 1), sample size (n), Tajima's neutrality test $(D)$, Fu's test of neutrality $(F s)$, Ramos-Onsins and Rozas statistic $\left(R_{2}\right), E T$ expansion times using the cox 1 mutation rate estimated from Muricinae fossils in the present study $(0.6 \%$ per Mya).

$* P<0.05, * * P<0.01, * * * P<0.001$.

species without a dispersing larva (e.g. Boissin et al., 2008) reported genetic structure at a small geographical scale. Studies comparing pairs of closely related species with contrasting larval dispersal (Tarnowska et al., 2012; Weber et al., 2015), as well as reviews of the literature (e.g. Selkoe \& Toonen, 2011), confirmed the influence of the initial life stage for benthic invertebrates.

\section{A MAJOR PHYLOGEOGRAPHICAL BREAK ACROSS THE STS OR ACROSS THE PELOPONNESE ARC}

A distinction between the Aegean and other populations was reported in other marine species and was associated with the phylogeographical barrier located at the straits of the Peloponnese arc. The so-called Peloponnese break opposes the western, Adriatic and central basins (including the Ionian Sea) to the Aegean and Levantine basins (Bahri-Sfar et al., 2000; Nikula \& Väinölä, 2003; Marzouk \& Saïd, 2017). An AegeanBlack Sea-Caspian Sea mitochondrial clade was also found in the bivalve Cerastoderma glaucum, which lives in a fragmented environment, the larvae of which have a short planktonic duration (Tarnowska et al., 2010). In a brittle-star species complex, this region also seems to represent a distribution limit for brooders (Weber, Stöhr \& Chenuil, 2014; Weber et al., 2015). By contrast, and unlike numerous species (e.g. Borsa, Blanquer \& Berrebi, 1997; Patarnello et al., 2007), there is no deep genetic differentiation between Atlantic and Mediterranean populations in $H$. trunculus, and several haplotypes are shared across the strait of Gibraltar and across the Almeria-Oran front. Phylogeographical breaks between the western and the eastern (including central) Mediterranean basins (located at the SiculoTunisian sill), and isolating the Adriatic Sea, have been reported for many marine invertebrates (e.g. Borsa et al., 1997; Pérez-Losada et al., 2007; Zitari-Chatti et al., 2008, 2009; Fadhlaoui-Zid et al., 2012; Villamor et al., 2014; Deli et al., 2015a; Deli, Said \& Chatti, 2015b). In H. trunculus, the Adriatic Sea was not associated with any deep divergence.

The parapatric distributions of the two main lineages strongly suggest that they arose by vicariance, i.e. their divergence is due to long-term separation without any genetic exchanges of their distribution ranges. Since lineage II also appears in southern Italy and in the STS, two scenarios appear equally likely. (1) Vicariance initially separated Aegean populations (possibly, together with Levantine populations) from all the other Mediterranean populations, subsequently followed by migration from the Aegean Sea to the west following the main currents, along the northern shores of the Mediterranean (the general Mediterranean coastal circulation is clockwise). If only Aegean populations were initially isolated by vicariance, they may subsequently have expanded towards the Levantine basin and westward towards southern Italy. (2) Vicariance separated two geographical areas across the STS, and was followed by colonization following the main clockwise Mediterranean currents, explaining the presence of lineage I along eastern Tunisian coasts and lineage II in southern Italy. Morphological data (Marzouk et $a l ., 2016)$, reflecting the average of many genes, and 
possibly the influence of environment, grouped eastern Tunisia and Adriatic with Aegean populations, and STS with western Mediterranean populations. They thus support the STS vicariance rather than the Peloponnese vicariance hypothesis. However, the presence of lineage $\mathbf{I}$ in the northern Adriatic Sea is not easily explained by an initial STS vicariance. This region was above sea level until very recently (after the last glacial maximum). Humans, large fishes or birds may have transported lineage I specimens to the Adriatic Sea (Green \& Figuerola, 2005).

Even though vicariance led to cryptic speciation in H. trunculus, hybridizations are now possible, as shown by recombined genotypes found in STS populations. Our data do not establish whether or not lineages I and II evolved genomic incompatibilities, and thus whether they can be considered as distinct species or subspecies. The non-significant exact tests (for association between lineages of different markers) could be the consequence of small sample sizes or of the analysis of genomic regions unlinked to genomic incompatibilities.

\section{HISTORICAL ISOLATION BETWEEN THE TWO PARAPATRIC LINEAGES, POSSIBLY CRYPTIC SPECIES}

For the two studied markers (cox1 and i29), the major split was estimated to have occurred about 5 Mya, which coincides with the Pliocene. This divergence time may be an overestimate because it was based on an older calibration point (40 Mya) (Ho et al., 2005). Using the mutation rate from gastropods separated by the Panama Isthmus (3.3 Mya) (phylogenetically distant from Hexaplex), led to a much more recent divergence, of 1 Mya. In Ho et al. (2005), the drastic changes of inferred rates with calibration times occurred between 0 and 2 Mya, and calibration points older than 2 Mya for mitochondrial DNA led to similar divergence rates. This suggests that time dependency of divergence rate is not responsible for the differences we found because the two calibration points leading to the conflicting divergence time estimations were older than 2 Mya. We thus favour a change in evolutionary rates among gastropods, and for this reason, we trust the times estimated from Muricinae fossils more than that of Panama one. The similar dates of divergence of the two lineages for the two independent markers lend additional support to the hypothesis that this major split corresponds to vicariance and not to selective sweeps (which can produce similar haplotype divergence patterns), because such sweeps are unlikely to occur simultaneously for distinct markers. This divergence estimate of $~ 5 \mathrm{Mya}$ is compatible with the end of the Messinian salinity crisis, during which the Mediterranean basin was split into several sub-basins with varying salinity, and may have led to allopatric divergence (eventually speciation) (Sabelli \& Taviani, 2014; Calvo et al., 2015). Lineages with distinct or allopatric geographic distributions were reported in other Mediterranean gastropods with a short larval phase, as in the muricid species complex Ocinebrina edwardsii (Barco et al., 2013) and the vermetid Dendropoma petraeum (Calvo et al., 2009, 2015). As for $H$. trunculus, their distribution also spanned the eastern Atlantic coasts and their history was probably similar. The distribution of individual mitochondrial lineages in these taxa is even more limited than in $H$. trunculus. Since the same marker was used (cox1) in all three taxa, their contrasted range sizes may have been caused by contrasted dispersal ability, habitat fragmentation or human introductions in $H$. trunculus. Since the banded murex has no larval stage, less fragmented habitat (e.g. greater depth range) and human introductions are the most likely explanations (see below).

We could not establish whether the genomes of the two lineages were perfectly compatible or not, that is whether hybrids resulting from crosses between the two lineages had lower fitness due to genomic incompatibilities, owing to restricted sample sizes in the sympatry area and to a limited number of loci. The location of this contact zone, concordant with other marine species' transition zones (Borsa et al., 1997), could be explained by a coupling between genetic incompatibilities (reduced or null fitness of the 'hybrids' or introgressed individuals), and exogenous limits to gene flow (differential survival of the two lineages in the environments separated by the contact zone or hydrodynamic limits) (Barton, 1979). It would be of interest to analyse more markers in order to assess the extent of genomic incompatibilities between the lineages.

In conclusion, in most of its distribution area, $H$. trunculus populations are composed of a single lineage, but there may be two cryptic species, currently hybridizing in the STS and possibly along southern Italian coasts. The absence of the whole western haplogroup I-1 $\mathbf{1}_{\mathrm{i} 29}$ in the STS suggests the historical isolation of these populations, favouring the ancient hybridization event hypothesis (current absence of parental species and F1 individuals). Since this typical haplogroup is not recovered with cox 1 , despite an earlier coalescence time of the mitochondrial genome, it is also likely that selective events led to the evolution of this i29 haplogroup in the STS. Additional markers and/or samples are needed to test the possible scenarios.

\section{DIFFERENT DEMOGRAPHIC HISTORIES IN THE TWO LINEAGES}

The neutrality tests, expansion parameter estimations and haplotype network shapes suggested that either demographic expansion had occurred or selective 
sweeps had affected the genetic markers. The globally similar shapes of the haplotype networks from the nuclear and the mitochondrial genes support the demographic rather than the selective explanation. In effect, a selective sweep would have occurred in lineage I (or occurred more recently in this lineage than lineage II) for both markers $\operatorname{cox} 1$ and $i 29$, to account for the data, which is a less parsimonious and less likely explanation than demographic expansion (Hoareau, 2016). Such haplotype network patterns were often related to expansion after periods of small effective population size caused by Pleistocene climatic fluctuations (Patarnello et al., 2007; Crandall et al., 2012). Using the cox 1 mutation rate estimated from Muricinae fossils in the present study, demographic expansion onset times range from $c$. 74 to 481 kya. Such estimations are affected differently according to the sampling scheme (Städler et al., 2009): in the case of expansion, the Tajima and Fu estimators are overestimated (leading to non-significant tests, even in case of true expansion). The results of these tests, interpreted as expansion signals, are therefore expected to be conservative. However, the time estimates of the expansion, in addition to their large confidence interval, may be strongly biased. The robust result is that the two lineages display a very distinct distribution of genetic diversity (illustrated by the different shapes of their haplotype networks), but it is difficult to separate the effect of demographic history from the effect of population structure in a quantitative way. The shapes of the haplotype networks and the expansion time estimates strongly suggest that the two lineages underwent distinct histories. During the Pleistocene period, H. trunculus populations may have undergone several size fluctuations. Populations from the Adriatic Sea are estimated to have the most recent demographic expansion (Table 2), in agreement with knowledge on sea levels and past climates that establish that nearly the whole of the Adriatic was emerged during the last glacial maximum, in contrast to other basins. However the expansion onset time estimated is too ancient to be explained directly by the recolonization of the Adriatic basin after its emersion. The low levels of nucleotide diversity of $H$. trunculus from Venice, Marseille, Alboran and Atlantic populations, as compared to those of the eastern Mediterranean, suggest that populations from the western part of the distribution range experienced severe genetic drift due to founder effects and/or bottlenecks. However, the haplotypes from the west are definitely not derived from eastern lineage haplotypes (e.g. Tarnowska et al., 2010; Ragionieri \& Schubart, 2013; and references therein), as shown by rooted phylogenetic trees for both markers, so one cannot conclude that the eastern basin played the role of a refugium for the distribution of the whole species. A similar contrast between eastern Mediterranean lineages or populations (displaying demographic stability) and those of the western Mediterranean ones (with signs of demographic expansion) has been reported in other marine invertebrates, including gastropods and bivalves (Tarnowska et al., 2010; Calvo et al., 2015).

\section{FISHERIES MANAGEMENT AND ARCHAEOLOGICAL IMPLICATIONS}

The abundance of this species of high commercial value was reported to have decreased in some places, probably due to over-harvesting (Vasconcelos et al., 2008). Our results suggest that $H$. trunculus may be considered as at least two main distinct management units, and the strong genetic differentiation within each basin may imply a need for an even smaller management scale. This approach is rarely followed, although it would be appropriate for other harvested Mediterranean species (e.g. Ledoux et al., 2010; Penant et al., 2013). Tunisia and southern Italy are the only places in the world where the two lineages were found together in the field. This is a source of strength, because there is more genetic diversity available for breeding and for adaptation to disturbances, but also a weak point, because (1) each lineage is at its range limit and (2) there are at least two stocks which probably cannot replenish one another. Our findings are potentially important for archaeology because this species provided a highly valuable dye, comparable in price with gold and precious metals, from Antiquity (more specifically since the time of the Minoan civilization) (Guckelsberger, 2013). The strong population structure and parapatric distribution of the two lineages suggest that living specimens were not translocated by humans or that if they were, they did not settle or reproduce efficiently, between the eastern and western Mediterranean (with the possible exception of Adriatic populations (see above). Interestingly, Merle \& Filippozzi (2005) reported the presence of exotic $H$. trunculus specimens in the basin of Arcachon, more than $1100 \mathrm{~km}$ from their natural range (Houart, 2001), and after more than $2 \mathrm{Myr}$ of absence in the regional fossil record. Determining the area of origin of this exotic population should be possible with our two molecular markers, given the highly significant genetic differentiation they reveal between population pairs.

\section{ACKNOWLEDGEMENTS}

The authors express their gratitude to Benlahcen RIJAL LEBLAD (INRH, Tanger-Morocco), Dimitris POURSANIDIS and Dr. Drosos KOUTSOUBAS (HCMR, Crete-Greece), Fréderic Zuberer (Pythéas Institute, Marseille-France), Davide TAGLIAPIETRA 
(CNR-ISMAR, Venice-Italy), Andrés Martínez-Lage (Universidad da Coruña, Spain), Zeid MARZOUK, Najeh BOUIDA and Marwene BOUIDA (Tunisia) for collaboration in the collection of samples. We acknowledge indirect support from the SCBM (Service Commun Biologie Moléculaire) of the IMBE. Didier Merle is thanked for his explanations of the complex fossil record situation. Abigail Cahill and Michael Paul are thanked for improving the final version of the manuscript and correcting the English. We thank the anonymous reviewers for their helpful comments. This work was supported by the Ministry of higher Education and Scientific Research of the Republic of Tunisia.

\section{REFERENCES}

AddinSoft. 2007. XLSTAT: analyse de données et statistique avec MS Excel. New York: AddinSoft.

Aires T, Marbà N, Cunha RL, Kendrick GA, Walker DI, Serrão EA, Duarte CM, Arnaud-Haond S. 2011. Evolutionary history of the seagrass genus Posidonia. Marine Ecology Progress Series 421: 117-130.

Anastasiou TI, Chatzinikolaou E, Mandalakis M, Arvanitidis C. 2016. Imposex and organotin compounds in ports of the Mediterranean and the Atlantic: is the story over? Science of the Total Environment 569: 1315-1329.

Aurelle D, Ledoux JB, Rocher C, Borsa P, Chenuil A, Feral JP. 2011. Phylogeography of the red coral (Corallium rubrum): inferences on the evolutionary history of a temperate gorgonian. Genetica 139: 855-869.

Bahri-Sfar L, Lemaire C, Ben Hassine OK, Bonhomme F. 2000. Fragmentation of sea bass populations in the western and eastern Mediterranean as revealed by microsatellite polymorphism. Proceedings of the Royal Society of London B: Biological Sciences 267: 929-935.

Bandelt HJ, Forster P, Rohl A. 1999. Median-joining networks for inferring intraspecific phylogenies. Molecular Biology and Evolution 16: 37-48.

Barco A, Houart R, Bonomolo G, Crocetta F, Oliverio M. 2013. Molecular data reveal cryptic lineages within the northeastern Atlantic and Mediterranean small mussel drills of the Ocinebrina edwardsii complex (Mollusca: Gastropoda: Muricidae). Zoological Journal of the Linnean Society 169: 389-407.

Barton N. 1979. Dynamics of hybrid zones. Heredity 43: 341-359.

Benjamini Y, Hochberg Y. 1995. Controlling the false discovery rate: a practical and powerful approach to multiple testing. Journal of the Royal Statistical Society: Series B 57: 289-300.

Boissin E, Egea E, Féral JP, Chenuil A. 2015. Contrasting population genetic structures in Amphipholis squamata, a complex of brooding and self-reproducing sister species sharing lifehistory traits. Marine Ecology Progress Series 139: 165-177.

Boissin E, Féral JP, Chenuil A. 2008. Defining reproductively isolated units in a cryptic and syntopic species complex using mitochondrial and nuclear markers: the brooding brittle star, Amphipholis squamata (Ophiuroidea). Molecular Ecology 17: 1732-1744.

Boissin E, Hoareau TB, Berrebi P. 2011a. Effects of current and historic habitat fragmentation on the genetic structure of the sand goby Pomatoschistus minutes (Osteichthys, Gobiidae). Biological Journal of the Linnean Society 102: 175-198.

Boissin E, Stöhr S, Chenuil A. 2011b. Did vicariance and adaptation drive cryptic speciation and evolution of brooding in Ophioderma longicauda (Echinodermata: Ophiuroidea), a common Atlanto-Mediterranean ophiuroid? Molecular Ecology 20: 4737-4755.

Borsa P, Blanquer A, Berrebi P. 1997. Genetic structure of the flounders Platichthys flesus and P. Stellatus at different geographic scales. Marine Biology 129: 233-246.

Calderón I, Garrabou J, Aurelle D. 2006. Evaluation of the utility of $C O I$ and ITS markers as tools for population genetic studies of temperate gorgonians. Journal of Experimental Marine Biology and Ecology 336: 184-197.

Calvo M, Alda F, Oliverio M, Templado J, Machordom A. 2015. Surviving the Messinian Salinity Crisis? Divergence patterns in the genus Dendropoma (Gastropoda:Vermetidae) in the Mediterranean Sea. Molecular Phylogenetics and Evolution 91: 17-26.

Calvo M, Templado J, Oliverio M, Machordom A. 2009. Hidden Mediterranean biodiversity: molecular evidence for a cryptic species complex within the reef building vermetid gastropod Dendropoma petraeum (Mollusca: Caenogastropoda). Biological Journal of the Linnean Society 96: 898-912.

Chenuil A, Hoareau TB, Egea E, Penant G, Rocher C, Aurelle D, Mokhtar-Jamai K, Bishop J, Boissin E, Diaz A, Krakau M, Luttikhuizen P, Patti F, Blavet N, Mousset S. 2010. An efficient method to find potentially universal population genetic markers, applied to metazoans. BMC Evolutionary Biology 10: 276.

Chiavarini S, Massanisso P, Nicolai P, Nobili C, Morabito R. 2003. Butyltins concentration levels and imposex occurrence in snails from the Sicilian coasts (Italy). Chemosphere 50: 311-319.

Crandall ED, Sbrocco EJ, DeBoer TS, Barber PH, Carpenter KE. 2012. Expansion dating: calibrating molecular clocks in marine species from expansions onto the Sunda Shelf following the Last Glacial Maximum. Molecular Biology and Evolution 29: 707-719.

Deli T, Bahles H, Said K, Chatti N. 2015a. Patterns of genetic and morphometric diversity in the marbled crab (Pachygrapsus marmoratus, Brachyura, Grapsidae) populations across the Tunisian coast. Acta Oceanologica Sinica 34: $49-58$.

Deli T, Said K, Chatti N. 2015b. Genetic Differentiation among Populations of the Green Crab Carcinus aestuarii (Nardo, 1847) (Brachyura, Carcinidae) from the Eastern and Western Mediterranean Coast of Tunisia. Acta Zoologica Bulgarica 67: 327-335.

Drummond AJ, Rambaut A. 2007. BEAST: Bayesian evolutionary analysis by sampling trees. BMC Evolutionary Biology 7: 214. 
Durand JD, Borsa P. 2015. Mitochondrial phylogeny of grey mullets (Acanthopterygii: Mugilidae) suggests high proportion of cryptic species. Comptes Rendus Biologies 338: 266-277.

Duran S, Palacin C, Becerro MA, Turon X, Giribet G. 2004. Genetic diversity and population structure of the commercially harvested sea urchin Paracentrotus lividus (Echinodermata: Echinoidea). Molecular Ecology 13: 3317-3328.

Egea E, David B, Choné T, Laurin B, Féral JP, Chenuil A. 2016. Morphological and genetic analyses reveal a cryptic species complex in the echinoid Echinocardium cordatum and rule out a stabilizing selection explanation. Molecular Phylogenetics and Evolution 94: 207-220.

Excoffier L, Lischer HEL. 2010. Arlequin suite ver 3.5: a new series of programs to perform population genetics analyses under Linux and Windows. Molecular Ecology Resource 10: $564-567$.

Fadhlaoui-Zid K, Knittweis L, Aurelle D, Nafkha C, Ezzeddine S, Fiorentino F, Ghmati H, Ceriola L, Jarboui O, Maltagliati F. 2012. Genetic structure of Octopus vulgaris (Cephalopoda, Octopodidae) in the central Mediterranean Sea inferred from the mitochondrial COIII gene. Comptes Rendus Biologies 335: 625-636.

Féral JP. 2002. How useful are the genetic markers in attempts to understand and manage marine biodiversity? Journal of Experimental Marine Biology and Ecology 268: 121-145.

Fernandez-Lopez de Pablo J, Gabriel S. 2016. El Collado shell midden and the exploitation patterns of littoral resources during the Mesolithic in the Eastern Iberian Peninsula. Quaternary International 407: 106-117.

Folmer O, Black M, Hoeh W, Lutz R, Vrijenhoek R. 1994. DNA primers for amplification of mitochondrial cytochrome c oxidase subunit I from diverse metazoan invertebrates. Molecular Marine Biology and Biotechnology 3: 294-299.

Fu YX. 1997. Statistical tests of neutrality of mutations against population growth, hitchhiking and background selection. Genetics 147: 915-925.

Gérard K, Guillotton E, Arnaud-Haond S, Aurelle D, Bastrop R, Chevaldonné P, Derycke S, Hannel R, Lapègue S, Lejeusne C, Mousset S, Ramsak A, Remerie T, Viard F, Féral JP, Chenuil A. 2013. PCR survey of 50 introns in animals: cross-amplification of homologous EPIC loci in eight non-bilaterian, protostome and deuterostome phyla. Marine Genomics 12: 1-8.

González-Tizón AM, Mercedes FM, Vasconcelos P, Gaspar MB, Martínez-Lage A. 2008. Genetic diversity in fishery-exploited populations of the banded murex (Hexaplex trunculus) from the southern Iberian Peninsula. Journal of Experimental Marine Biology and Ecology 363: 35-41.

Green A, Figuerola J. 2005. Recent advances in the study of long-distance dispersal of aquatic invertebrates via birds. Diversity and Distributions 11: 149-156.

Guckelsberger M. 2013. Purple murex dye in antiquity. Thesis, University of Iceland.
Guindon S, Lethiec F, Duroux P, Gascuel O. 2005. PhyML Online a web server for fast maximum likelihood based phylogenetic inference. Nucleic Acids Research 33: 557-559.

Hall TA. 1999. Bioedit: a user-friendly biological sequence alignment editor and analysis program for Windows 95/98/ NT. Nucleic Acids Symposium Series 41: 95-98.

Hasegawa M, Kishino H, Yano T. 1985. Dating of the human-ape splitting by a molecular clock of mitochondrial DNA. Journal of Molecular Evolution 22: 160-174.

Hellberg ME. 2009. Gene flow and isolation among populations of marine animals. Annual Review of Ecology Evolution and Systematics 40: 291-310.

Ho SY, Phillips MJ, Cooper A, Drummond AJ. 2005. Time dependency of molecular rate estimates and systematic overestimation of recent divergence times. Molecular Biology and Evolution 22: 1561-1568.

Hoareau TB. 2016. Late glacial demographic expansion motivates a clock overhaul for population genetics. Systematic Biology 65: 449-464.

Houart R. 2001. A review of the recent Mediterranean and Northeastern Atlantic species of Muricidae. Rome: Edition Evolver.

Huson DH, Bryant D. 2016. Application of phylogenetic networks in evolutionary studies. Molecular Biology and Evolution 23: 254-267.

Kelly RP, Palumbi SR. 2010. Genetic structure among 50 species of the north eastern Pacific rocky intertidal community. PLoS ONE 5: 13.

Knowlton N. 1993. Sibling species in the sea. Annual Review of Ecology, Evolution, and Systematics 24: 189-216.

Krebes L, Blank M, Jürss K, Zettler ML, Bastrop R. 2010. Glacial-driven vicariance in the amphipod Gammarus duebeni. Molecular Phylogenetics and Evolution 54: 372-385.

Ledoux JB, Mokhtar-Jamaï K, Roby C, Féral JP, Garrabou J, Aurelle D. 2010. Genetic survey of shallow populations of the Mediterranean red coral [Corallium rubrum (Linnaeus, 1758)]: new insights into evolutionary processes shaping nuclear diversity and implications for conservation. Molecular Ecology 19: 675-690.

Lessios HA. 2008. The great American schism: divergence of marine organisms after the rise of the Central American Isthmus. Annual Review of Ecology, Evolution, and Systematics 39: 63-91.

Li WH. 1977. Distribution of nucleotide differences between two randomly chosen cistrons in a finite population. Genetics 85: 331-337.

Librado P, Rozas J. 2009. DnaSP v5: a software for comprehensive analysis of DNA polymorphism data. Bioinformatics 25: 1451.

Maggs CA, Castilho R, Foltz D, Henzler C, Jolly MT, Kelly J, Olsen J, Perez KE, Stam W, Vainola R, Viard F, Wares J. 2008. Evaluating signatures of glacial refugia for North Atlantic benthic marine taxa. Ecology 89: S108-S122.

Maltagliati F, Di Giuseppe G, Barbieri M, Castelli A, Dini F. 2010. Phylogeography and genetic structure of the edible sea urchin Paracentrotus lividus (Echinodermata: 
Echinoidea) inferred from the mitochondrial cytochrome $b$ gene. Biological Journal of the Linnean Society 100: 910-923.

Marzouk Z, Chenuil A, Blel H, Said K. 2016. Morphometric variation of fishery-exploited Muricidae (Hexaplex trunculus) in the Mediterranean Sea and the Northeastern Atlantic Ocean: Implications for stock identification. Turkish Journal of Fisheries and Aquatic Sciences 16: 327-338.

Marzouk Z, Saïd K. 2017. Genetic variability of the banded Murex (Hexaplex trunculus) revealed by ND2 and ITS2 sequences. Russian Journal of Marine Biology 43: 92-98.

Mayr E. 1942. Systematic and the origin of species. New York: Columbia University Press.

Merle D, Filippozzi D. 2005. First record of Trunculariopsis trunculus (Linnaeus, 1758) (Mollusca: Gastropoda) from the basin of Arcachon (Gironde): the second exotic muricid on the French Atlantic coasts. Cahiers de Biologie Marine 46: 299-303.

Merle D, Garrigues B, Pointier JP. 2011. Fossil and recent Muricidae of the World: Part Muricinae. Hackenheim: Conchbooks.

Miura O, Torchin ME, Bermingham E. 2010. Molecular phylogenetics reveals differential divergence of coastal snails separated by the Isthmus of Panama. Molecular Phylogenetics and Evolution 56: 40-48.

Modica MV, Mariottini P, Prkić J, Oliverio M. 2013. DNA-barcoding of sympatric species of ectoparasitic gastropods of the genus Cerithiopsis (Mollusca: Gastropoda: Cerithiopsidae) from Croatia. Journal of the Marine Biological Association of the United Kingdom 93: 1059-1065.

Nikula R, Väinölä R. 2003. Phylogeography of Cerastoderma glaucum (Bivalvia: Cardiidae) across Europe: a major break in the Eastern Mediterranean. Marine Biology 143: 339-350.

Patarnello T, Volckaert FA, Castilho R. 2007. Pillars of Hercules: is the Atlantic-Mediterranean transition a phylogeographical break? Molecular Ecology 16: 4426-4444.

Penant G, Aurelle D, Feral J, Chenuil A. 2013. Planktonic larvae do not ensure gene flow in the edible sea urchin Paracentrotus lividus. Marine Ecology Progress Series 480: 155-170.

Pérez-Losada M, Nolte MJ, Crandall KA, Shaw PW. 2007. Testing hypotheses of population structuring in the Northeast Atlantic Ocean and Mediterranean Sea using the common cuttlefish Sepia officinalis. Molecular Ecology 16: 2667-2679.

Posada D. 2008. jModelTest: phylogenetic model averaging. Molecular Biology and Evolution 25: 1253-1256.

Ragionieri L, Schubart CD. 2013. Population genetics, gene flow, and biogeographical boundaries of Carcinus aestuarii (Crustacea: Brachyura: Carcinidae) along the European Mediterranean coast. Biological Journal of the Linnean Society 109: 771-790.

Rambaut A. 2009. FigTree version 1.3.1 [computer program]. Available at: http://tree.bio.ed.ac.uk

Ramos-Onsins SE, Rozas J. 2002. Statistical properties of new neutrality tests against population growth. Molecular Biology and Evolution 19: 2092-2100.
Ratnasingham S, Hebert PD. 2013. A DNA-based registry for all animal species: the barcode index number (BIN) system. PLoS ONE 8: e66213.

Reuschel S, Schubart CD. 2006. Phylogeny and geographic differentiation of Atlanto-Mediterranean species of the genus Xantho (Crustacea: Brachyura: Xanthidae) based on genetic and morphometric analyses. Marine Biology 148: 853-866.

Rogers AR, Harpending H. 1992. Population growth makes waves in the distribution of pairwise genetic differences. Molecular Biology and Evolution 9: 552-569.

Sabelli B, Taviani M. 2014. The making of the Mediterranean Molluscan biodiversity. In: Goffredo S, Dubinsky Z, eds. The Mediterranean Sea: its history and present challenges. Dordrecht: Springer Science+Business Media, 285-306.

Schneider S, Excoffier L. 1999. Estimation of past demographic parameters from the distribution of pairwise differences when the mutation rates vary among sites: application to human mitochondrial DNA. Genetics 152: 1079-1089.

Selkoe KA, Toonen RJ. 2011. Marine connectivity: a new look at pelagic larval duration and genetic metrics of dispersal. Marine Ecology Progress Series 436: 291-305.

Städler T, Haubold B, Merino C, Stephan W, Pfaffelhuber P. 2009. The impact of sampling schemes on the site frequency spectrum in nonequilibrium subdivided populations. Genetics 182: 205-216.

Tajima F. 1989. Statistical testing for the neutral mutation hypothesis by DNA polymorphism. Genetics 123: 585-595.

Tamura K, Peterson D, Peterson N, Stecher G, Nei M, Kumar S. 2011. MEGA5: molecular evolutionary genetics analysis using maximum likelihood, evolutionary distance, and maximum parsimony methods. Molecular Biology and Evolution 28: 2731-2739.

Tarnowska K, Chenuil A, Nikula R, Féral JP, Wolowicz M. 2010. Complex genetic population structure of the bivalve Cerastoderma glaucum in a highly fragmented lagoon habitat. Marine Ecology Progress Series 406: 173-184.

Tarnowska K, Krakau M, Jacobsen S, Wołowicz M, Féral JP, Chenuil A. 2012. Comparative phylogeography of two sister (congeneric) species of cardiid bivalve: strong influence of habitat, life history and post-glacial history. Estuarine Coastal and Shelf Science 107: 150-158.

Thompson JD, Higgins DG, Gibson TJ. 1994. CLUSTAL W: improving the sensitivity of progressive multiple sequence alignment through sequence weighting, position-specific gap penalties and weight matrix choice. Nucleic Acids Research 22: 4673-4680.

Valenzuela OA. 2015. An ancient fishery of Banded dye-murex (Hexaplex trunculus): zooarchaeological evidence from the Roman city of Pollentia (Mallorca, Western Mediterranean). Journal of Archaeological Science 54: 1-7.

Vasconcelos P, Carvalho S, Castro M, Gaspar MB. 2008. The artisanal fishery for muricid gastropods (banded murex and purple dye murex) in the Ria Formosa lagoon (Algarve coast - southern Portugal). Scientia Marina 72: 287-298.

Vasconcelos P, Gaspar MB, Joaquim S, Matias D, Castro M. 2004. Spawning of Hexaplex (Trunculariopsis) trunculus (Gastropoda:Muricidae)inthelaboratory:description of spawning 
behaviour, egg masses, embryonic development, hatchling and juvenilegrowth rates.Invertebrate Reproduction Development 46: $125-138$.

Villamor A, Costantini F, Abbiati M. 2014. Genetic structuring across marine biogeographic boundaries in rocky shore invertebrates. PLoS ONE 9: e101135.

Walsh PS, Metzger DA, Higuchi R. 1991. Chelex 100 as a medium for simple extraction of DNA for PCR-based typing from forensic material. BioTechniques 10: 506-513.

Weber AA, Mérigot B, Valière S, Chenuil A. 2015. Influence of the larval phase on connectivity: strong differences in the genetic structure of brooders and broadcasters in the Ophiodermalongicauda speciescomplex.MolecularEcology 24: 6080-6094.

Weber AA, Stöhr S, Chenuil A. 2014. Genetic data, reproduction season and reproductive strategy data support the existence of biological species in Ophioderma longicauda. Comptes Rendus Biologies 337: 553-560.

Zarai Z, Balti R, Mejdoub H, Gargouri Y, Sayari A. 2012. Process for extracting gelatin from marine snail (Hexaplex trunculus): chemical composition and functional properties. Process Biochemistry 47: 1779-1784.

Zitari-Chatti R, Chatti N, Elouaer A, Said K. 2008. Genetic variation and population structure of the caramote prawn Penaeus kerathurus (Forskäl) from the eastern and western Mediterranean coasts in Tunisia. Aquaculture Research 39: $70-76$.

Zitari-Chatti R, Chatti N, Fulgione D, Caiazza I, Aprea G, Elouaer A, Said K, Capriglione T. 2009. Mitochondrial DNA variation in the caramote prawn Penaeus (Melicertus) kerathurus across a transition zone in the Mediterranean Sea. Genetica 136: 439-447.

\section{SUPPORTING INFORMATION}

Additional Supporting Information may be found in the online version of this article at the publisher's web-site:

Appendix S1. Haplotype networks for cox1 including sequences from Villamor et al. (2014) and the BOLDsystem database (Ratnasingham \& Hebert, 2013).

Appendix S2. $F_{\mathrm{ST}}$ (below the diagonal) and $\Phi_{\mathrm{ST}}$ (above the diagonal) between different populations. Not significantly different values after the multiple correction tests are written in bold.

Appendix S3. Non-parametric multidimensional scaling analyses (MDS) based on $\Phi_{\mathrm{ST}}$ distances between populations for each marker.

Appendix S4. Contingency tables comparing main splits for cox1 and i29 markers, in STS populations.

Appendix S5. Pairwise mismatch distribution for cox1 marker.

Appendix S6. Pairwise mismatch distribution for $i 29$ marker.

Appendix S7. GenBank accession numbers of all haplotypes for both markers. 